\title{
Analisis Kesalahan Siswa Kelas VII dalam Menyelesaikan Soal Himpunan Ditinjau dari Gaya Kognitif
}

\author{
Natasya Yoesepa Dwi Utami ${ }^{1}$, Sukirwan ${ }^{2}$, Yani Setiani ${ }^{3}$ \\ ${ }^{1,2}$ Program Studi Pendidikan Matematika, Fakultas Keguruan dan Ilmu Pendidikan, Universitas Sultan Ageng Tirtayasa, \\ Jl. Ciwaru Raya No.25, Cipare, Kota Serang, Indonesia \\ natasyayoesepa@gmail.com
}

\begin{abstract}
This study aims to determine student errors in solving set problems seen from students' cognitive styles. The method used is the descriptive method with a qualitative approach, sampling is done by purposive sampling technique. The study was conducted on seventh-grade students of SMP DAAR EL-ROFA. The instruments in this study include the GEFT test, set questions, and interviews. Data collection techniques used are documentation, tests, and interviews. The validity of the data using the triangulation method. The data analysis technique uses data reduction, data presentation, and concluding. The results showed that the students' errors of the field independent type were at the stage of planning problem solving, implementing the problem-solving plans, and looking back. Meanwhile, students with the field-dependent type make mistakes at the stage of understanding the problem, planning problem solving, carrying out problem-solving plans, and looking back. It can be concluded that the errors made by FI-type students are less than those of FD-type students.
\end{abstract}

Keywords: Student Error, Set, Cognitive Style

\begin{abstract}
Abstrak
Penelitian ini bertujuan untuk mengetahui kesalahan siswa dalam menyelesaikan soal himpunan dilihat dari gaya kognitif siswa. Metode yang digunakan adalah metode deskriptif dengan pendekatan kualitatif, pengambilan sampel dilakukan dengan Teknik purposive sampling. Penelitian dilakukan pada siswa kelas VII SMP DAAR EL-ROFA. Intrumen dalam penelitian ini diantaranya tes GEFT, soal Himpunan dan wawancara. Teknik pengumpulan data yang digunakan yaitu dokumentasi, tes, dan wawancara. Keabsahan data menggunakan metode triangulasi. Teknik analisis data menggunakan reduksi data, penyajian data, dan penarikan kesimpulan. Hasil penelitian menunjukan bahwa kesalahan siswa tipe field independent terdapan pada tahap merencanakan penyelesaian masalah, melaksanakan rencana penyelesaian masalah, dan melihat kembali. Sedangkan siswa dengan tipe field dependent melakukan kesalahan pada tahap memahami masalah, merencanakan penyelesaian masalah, melaksanakan rencna penyelesaian masalah, dan melihat kembali. Hal tersebut dapat disimpulkan bahwa kesalahan yang dilakukan siswa tipe FI lebih sedikit dibandingkan dengan siswa tipe FD.
\end{abstract}

Kata kunci: Kesalahan Siswa, Himpunan, Gaya Kognitif

Copyright (c) 2021 Natasya Yoesepa Dwi Utami, Sukirwan, Yani Setiani

$\triangle$ Corresponding author: Natasya Yoesepa Dwi Utami

Email Address: natasyayoesepa@gmail.com (Jl. Ciwaru Raya No.25, Cipare, Indonesia)

Received 08 June 2021, Accepted 11 July 2021, Published 16 August 2021

\section{PENDAHULUAN}

Pembelajaran matematika berada pada posisi yang sangat penting untuk mencapai tujuan pendidikan nasional. Matematika dapat menjadi dasar ilmu-ilmu lain untuk mengajarkan siswa berpikir sistematis, analitis, dan logis. Matematika merupakan salah satu tugas yang sulit dan tidak menarik, sering diartikan sebagai persepsi negatif terhadap matematika. Keberhasilan pembelajaran matematika dapat dibuktikan dengan keberhasilan siswa yang mengikuti kegiatan pembelajaran tersebut. Keberhasilan tersebut tercermin dari kemampuan siswa dalam memahami konsep dan materi dalam bidang matematika. Pembelajaran matematika menggunakan simbol, notasi, dan diagram dari kumpulan data, dan karena merupakan data konseptual maka terdapat materi himpunan yang tidak banyak menggunakan rumus. Mahasiswa perlu memahami definisi himpunan dan notasi, memahami konsep 
himpunan bagian, dan menguasai data himpunan dengan kemampuan dasar seperti mengiris himpunan, kombinasi, minus dan perilaku komponen. Diagram Venn, solusi untuk masalah penggunaan himpunan dalam himpunan.

Keberhasilan kurikulum matematika dapat dilihat dari keberhasilan siswa yang terlibat dalam kegiatan pembelajaran tersebut. Keberhasilan dapat dilihat dari kemampuan siswa dalam memahami konsep dan materi dalam bidang matematika. Semakin tinggi tingkat keberhasilan siswa, maka semakin tinggi pula kemampuan siswa dalam memahami konsep dan materi. Namun kenyataan di lapangan menunjukkan bahwa pemahaman siswa terhadap konsep dan materi di bidang matematika masih rendah, sehingga mempengaruhi prestasi belajar pada mata pelajaran matematika. Masih banyak siswa yang takut dengan matematika dan tidak suka bertemu dengan siswa yang tidak terlalu pandai matematika. Anggapan tersebut tentunya membuat siswa kurang termotivasi untuk belajar matematika dan menyulitkan anak untuk belajar matematika. Kesulitan yang dihadapi siswa dalam belajar matematika berdampak pada kesalahan dalam menyelesaikan masalah matematika. Hal ini terjadi karena siswa belum memahami dan mengetahui materi dan konsep matematika. Ketika mengajukan pertanyaan, kesalahan siswa dapat menjadi petunjuk untuk menemukan faktor-faktor yang mempengaruhi prestasi siswa. Mengetahui faktor-faktor ini dapat digunakan untuk mengurangi kesalahan yang dibuat siswa saat menyelesaikan masalah matematika.

Dalam matematika, disebut himpunan semua kumpulan dari objek tertentu yang disebut unit. Himpunan adalah salah satu dasar matematika. Konsep dasar yang terdapat dalam matematika dikembalikan ke dalam konsep himpunan. Misalnya, garis adalah kumpulan titik. Disadari atau tidak, ini adalah kumpulan materi yang sering digunakan dalam kehidupan sehari-hari, seperti arisan dan studi tentang harta warisan. Mengingat bahwa buku teks dalam himpunan merupakan dasar-dasar matematika yang sangat penting, diharapkan siswa dapat memahami dan menguasainya. Hal ini dapat diketahui dari kesalahan siswa pada saat pemecahan masalah untuk memahami kemahiran siswa terhadap materi yang ditetapkan. Menurut Malau (1996), beberapa kesalahan yang sering dilakukan siswa saat menyelesaikan soal matematika adalah penyebab kesalahan yang sering mereka lakukan saat menyelesaikan soal matematika, memahami asumsi dan tema yang mereka praktikkan, termasuk kekurangan dan kekurangannya. Perolehan bahasa matematika, salah tafsir dan penerapan rumus, salah perhitungan, kurang teliti dan lupa konsep. Pemecahan masalah dapat diterapkan selama proses pembelajaran untuk mengatasi kesalahan. Oleh karena itu, tujuan utama pendidikan matematika pemecahan masalah merupakan salah satu dan merupakan bagian penting dari kegiatan matematika. Di sisi lain, menurut (Polya 2004), untuk memecahkan masalah matematika, ada empat langkah: memahami masalah (memahami masalah), rencana pemecahan masalah (plan), dan melaksanakan (eksekusi) rencana pemecahan masalah rencana) untuk meninjau solusi. Saya bisa mendapatkan (berbalik).

Menurut hasil penelitian (Wahyuni, 2016), penerapan pendekatan pemecahan masalah model Polya dapat meningkatkan hasil belajar siswa ketika menyelesaikan masalah berbicara pada topik persegi panjang, yang memudahkan siswa. Berikut empat langkah yang harus dilakukan untuk 
membuatnya. Untuk memusatkan perhatian pada pemecahan masalah, lihat kembali matematika, yaitu 1) masalah, 2) perencanaan, 3) pelaksanaan rencana, dan 4) penyelesaian lengkap. Begitu pula pada hasil penelitian yang lainnya, menunjukan bahwa dalam penelitian (Kristofora \& Sujadi, 2017) yang menyatakan terdapat empat jenis kesalahan. Dimana hasilnya menunjukan siswa lebih dominan melakukan kesalahan pada tahap memahami masalah.

Pada penelitian ini peneliti menggunakan gaya kognitif Field Dependent dan Field Independent. Alasan menggunakan gaya kognitif ini dilakukan agar dapat menggunakan instrument test GEFT ( group embedded figure test). Dikarenakan pengambilan objek dalam penelitian ini merupakan siswa atau siswi SMP yang berusia sekitar 10 tahun keatas maka akan terlihat akan adanya sebuah perbedaan dari kedua gaya kognitif mendasar tersebut yakni bagaimana siswa dapat melihat suatu permasalahan. Dari beberapa penelitian yang telah ditemukan terdapat fakta bahwa siswa dengan gaya kognitif Field Independent memiliki kecenderung dalam analitis untuk meihat masalah dibandingkan dengan siswa gaya kognitif dependent. Menurut hasil penelitian (Jannah, 2019) kesalahan siswa tipe Field Independent terdapat tiga langkah sedangkan untuk kesalahan siswa tipe dependent yaitu terdapat ada empat langkah.

Pada penelitian sebelumnya (Nuurul, 2017) mengatakan tentang perbedaan gaya kognitif FI dan FD dalam memecahkan masalah yaitu: (1) Pada siswa laki laki kelas VII SMP yang di lakukan dengan kognitif FI dapat menyelesaikan Permasalahan matematika dengan baik atau lengkap. (2) Pada siswi perempuan kelas VII SMP yang di lakukan dengan kognitif FI dapat menyelesaikan permasalahan matematika dengan baik akan tetapi kurang meyakinkan. (3) Pada siswa laki-laki kelas VII SMP dengan yang di lakukan dengan gaya kognitif FD dapat menyelesaikan permasalahan matematika dengan baik akan tetapi kurang teliti.

Pada dasarnya pembelajaran matematika SMP mencakup banyak materi, materi matemematika SMP ialah materi himpunan kelas VII SMP semester 1. Salah satu bagian dari materi tersebut ada pada pembelajaran sebuah matematika yang dimana penguasaan materi juga pemahaman konsep oleh siswa, sehingga siswa tersebut dapat meningkatkan sebuah prestasi dalam keseluruhanya. Pemahaman materi juga konsep yang di lakukan oleh siswa dapat dilihat dari hasil penyelesaian soal yang berhasil dijawab. Dalam hasil dari soal yang telah di kerjakan oleh siswa terdapat kesalahan kesalahan siswa dalam menyelesaikan persoalan dalam materi himpunan salah satunya.

Pada hasil penelitian (Cahyani \& Sutriyono, 2018) didapatkan kesimpulan bahwa siswa dengan kemampuan yang rendah mengerjakan soal kesalahan pada keseluruhan tahapan antara lain kesalahan dalam memahami soal, membaca, keterampilan dan transformasi, sedangkan pada siswa dengan kemampuan menengah atau sedang terdapat kesalahan dalam tahapan membaca, selain itu siswa dengan kemampuan tinggi dapat melakukan kesalahan keterampilan dan transformasi.

Dengan demikian dari permasalahan yang telah didapatkan peneliti mencoba untuk menganalisis apa saja kesalahan yang dilakukan oleh siswa kelas VII SMP Daar El-Rofa dalam menyelesaikan soal Himpunan. Adapun tahap tahapan yang di lakukan penulis dengan menganalisis kesalahan yang dapat 
dilakukan pada soal Himpunan berdasarkan tahapan Polya juga dilihat dari gaya kognitif masing masing siswa. Hal ini dimaksudkan untuk dapat mengetahui kesalahan yang di lakukan oleh siswa sehingga dapat ditentukan solusinya.

\section{METODE}

Jenis penelitian ini adalah penelitian deskriptif dengan pendekatan kualitatif. Penelitian deskriptif digunakan untuk melihat dan menggambarkan masalah atau fakta yang sedang terjadi yang diungkapkan tanpa ada manipulasi (Sugiyono, 2010) Penelitian ini dilakukan di SMP DAAR EL ROFA Lebak Banten. Peneliti memilih sekolah ini karena saat akan melakukan penelitian hanya sekolah ini yang melakukan pembelajaran secara luring. Dan juga lebih mudah meminta izin penelitian disana karena sekolah nya terbilang baru. Subjek penelitiannya adalah siswa/i kelas VII di SMP DAAR EL ROFA tahun pelajaran 2020/2021. Peneliti memilih siswa kelas VII karena materi tes yang digunakan adalah materi himpunan yang ada di kelas VII. Pada penelitian ini dalam menentukan subjek penelitian dipilih secara purposive sampling, dimana teknik purposive sampling ialah teknik penentuan sampel berdasarkan pertimbangan tujuan yang telah ditetapkan oleh peneliti, karena itu pengambilan sampel secara purposive tidak memperhatikan prinsip keterwakilan dari populasi (Barlian, 2016).

Instrumen dalam penelitian ini meliputi Tes Group Embedded Figure Test. (GEFT), soal Himpunan, dan pedoman wawancara. Dimana Tes GEFT merupakan tes yang digunakan untuk mengetahui gaya kognitif pada setiap siswa. Soal Tes GEFT dapat di unduh dari www.scribd.com. Tes GEFT adalah tes di mana setiap individu diarahkan untuk mencari bentuk sederhana pada bentuk yang lebih kompleks, yang dirancang untuk menyembunyikan bentuk sederhana tersebut. GEFT merupakan tes baku di Amerika, sehingga perubahan pada GEFT sedapat mungkin tidak dilakukan. Sebelum digunakan, ketiga instrument telah di validasi oleh para ahli (expert judgment). Teknik pengumpulan data dalam penelitian ini menggunakan teknik tes dan non tes. Teknik tes digunakan untuk mengetahui gaya kognitif siswa dan juga dilakukan untuk mengidentifikasi kesalahan siswa dalam menyelesaikan soal himpunan. Teknik non tes dilakukan melalui proses wawancara dengan subjek penelitian untuk mengetahui letak kesalahan siswa dalam mengolah soal himpunan dengan langkah Polya dan pendokumentasian seluruh proses penelitian dan hasil tes. Analisis data secara mendalam dilakukan terhadap kesalahan-kesalahan yang dilakukan subjek dalam mengolah soal himpunan setelah siswa digolongkan berdasarkan gaya kognitifnya.

\section{HASIL DAN DISKUSI}

Berdasarkan Tes GEFT yang diberikan kepada 23 siswa kelas VII SMP DAAR ER ROFA, terdapat 11 siswa yang bergaya kognitif FI dan 12 siswa yang bergaya kognitif FD. Selanjutnya dipilih 3 sampel dengan skor tinggi, sedang, dan rendah dari masing - masing gaya kognitif. Kemudian keenam siswa tersebut diberi tes berupa soal himpunan. Setelah selesai mengerjakan soal himpunan kemudian diberikan tes wawancara mengenai langkah penyelesaiannya. Berikut ini akan diberikan hasil jawaban 
dari siswa sesuai dengan gaya kognitifnya kemudian dianalisis jenis kesalahan berdasarkan Teori Polya.

\section{Kesalahan Siswa dengan Tipe Field Independent dalam Menyelesaikan Soal Himpunan}

Subjek yang pilih sebagai siswa dengan tipe FI adalah Dias (S-1), Zaki (S-2) dan Marliana (S-3). Dibawah ini peneliti mendeskripsikan hasil dari tes yang telah dilakukan. Berikut table deskripsi kesalahan siswa dalam menyelesaikan soal himpunan pada siswa tipe FI.

Tabel 1. kesalahan siswa FI dalam menyelesaikan soal himpunan

\begin{tabular}{|c|c|c|c|c|c|c|c|c|c|c|}
\hline \multirow[b]{2}{*}{ Indikator } & & \multicolumn{3}{|c|}{ Subjek S-1 } & \multicolumn{3}{|c|}{ Subjek S-2 } & \multicolumn{3}{|c|}{ Subjek S-3 } \\
\hline & & $\begin{array}{c}\text { Soal } \\
1\end{array}$ & $\begin{array}{c}\text { Soal } \\
2\end{array}$ & $\begin{array}{c}\text { Soal } \\
3\end{array}$ & $\begin{array}{c}\text { Soal } \\
1\end{array}$ & $\begin{array}{c}\text { Soal } \\
2\end{array}$ & $\begin{array}{c}\text { Soal } \\
3\end{array}$ & $\begin{array}{c}\text { Soal } \\
1\end{array}$ & $\begin{array}{c}\text { Soal } \\
2\end{array}$ & $\begin{array}{c}\text { Soal } \\
3\end{array}$ \\
\hline \multirow{2}{*}{$\begin{array}{l}\text { Memahami } \\
\text { masalah }\end{array}$} & + & $\sqrt{ }$ & $\sqrt{ }$ & $\sqrt{ }$ & $\sqrt{ }$ & $\sqrt{ }$ & & $\sqrt{ }$ & & $\sqrt{ }$ \\
\hline & - & & & & & & $\sqrt{ }$ & & $\sqrt{ }$ & \\
\hline \multirow{2}{*}{$\begin{array}{l}\text { Membuat } \\
\text { rencana }\end{array}$} & + & $\sqrt{ }$ & $\sqrt{ }$ & $\sqrt{ }$ & $\sqrt{ }$ & $\sqrt{ }$ & $\sqrt{ }$ & $\sqrt{ }$ & & \\
\hline & - & & & & & & & & $\sqrt{ }$ & $\sqrt{ }$ \\
\hline \multirow{2}{*}{$\begin{array}{c}\text { Melaksanakan } \\
\text { rencana }\end{array}$} & + & & & $\sqrt{ }$ & $\sqrt{ }$ & $\sqrt{ }$ & $\sqrt{ }$ & $\sqrt{ }$ & & \\
\hline & - & $\sqrt{ }$ & $\sqrt{ }$ & & & & & & $\sqrt{ }$ & $\sqrt{ }$ \\
\hline \multirow{2}{*}{$\begin{array}{l}\text { Melihat } \\
\text { Kembali }\end{array}$} & + & $\sqrt{ }$ & $\sqrt{ }$ & $\sqrt{ }$ & & & & $\sqrt{ }$ & & \\
\hline & - & & & & $\sqrt{ }$ & $\sqrt{ }$ & $\sqrt{ }$ & & $\sqrt{ }$ & $\sqrt{ }$ \\
\hline
\end{tabular}

Keterangan (+) Memenuhi Indikator

\section{(-) Tidak Memenuhi Indikator}

Berdasarkan analisis pada tiap indikator langkah penyelesaian masalah menurut Polya pada siswa dengan tipe FI adalah sebagai berikut.

\section{Memahami Masalah}

Berdasarkan hasil jawaban tes menyelesaikan soal Himpunan subjek S-1, S-2 dan S-3 sudah memenuhi tahap memahami masalah.hal ini dapat dilihat pada gambar dibawah bahwa siswa mampu menuliskan apa saja yang diketahui dalam soal, dan apa yang ditanyakan dalam soal tersebut. Hal ini sependapat dengan penelitian Khairunnisa dan Nining (2017) bahwa siswa mampu menjelaskan informasi apa saja yang ada pada soal, informasi itu nantinya akan digunakan untuk memecahkan permasalahan yang telah diberikan. Pernyataan tersebut didukung oleh salah satu hasil wawancara dan hasil tes soal Himpunan yang telah dilakukan dengan subjek sebagai berikut.

$P \quad$ : Coba jelaskan apa saja yang kamu pahami dalam soal ini?

S-2 : Jumlah masyarakat lebak 50, masyarakat yang suka madu baduy 25, dan masyarakat yang suka madu hitam 20

\section{Merencanakan Penyelesaian Masalah}

Berdasarkan hasil jawaban siswa pada tes soal Himpunan subjek S-1 dan S-2 sudah memenuhi indikator. Tetapi subjek S-3 hanya satu soal saja yang ia pahami. Subjek dapat merencanakan apa yang harus dilakukan, bermodalkan informasi yang diketahui dalam soal. Hal tersebut didukung dengan hasil penelitian yang dilakukan oleh Sulistyorini \& Nining (2016) bahwa siswa bisa membuat model matematika berdasarkan apa yang diketahui dan ditanyakan dari soal tapi masih belum lengkap. 


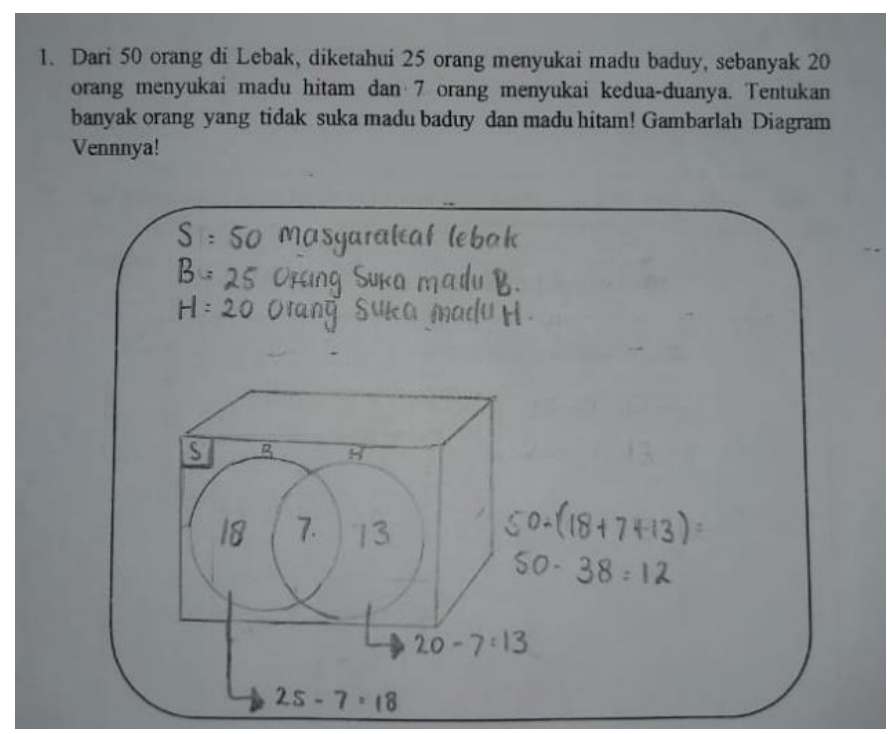

Gambar 1. Hasil Subjek S-2

\section{Merencanakan Penyelesaian Masalah}

Berdasarkan hasil jawaban siswa pada tes soal Himpunan subjek S-1 dan S-2 sudah memenuhi indikator. Tetapi subjek S-3 hanya satu soal saja yang ia pahami. Subjek dapat merencanakan apa yang harus dilakukan, bermodalkan informasi yang diketahui dalam soal. Hal tersebut didukung dengan hasil penelitian yang dilakukan oleh Sulistyorini \& Nining (2016) bahwa siswa bisa membuat model matematika berdasarkan apa yang diketahui dan ditanyakan dari soal tapi masih belum lengkap.

\section{Melaksanakan Perencanaan}

Berdasarkan hasil jawaban tes soal himpunan subjek S-1 dan S-3 belum memenuhi tahap melaksanakan perencanaan penyelesaian masalah, dan mengalami kesalahan pada tahap ini. Hal tersebut dapat dikaitkan dengan penelitian yag dilakukan oleh Wijaya \& Nining (2018) bahwa penyebab kesalahan yang dilakukan siswa FI dalam tahap melakukan proses ialah masih kuang terampil dalam menghitung, masih terbalik dalam mensubtitusikan, serta masih kurang cermat dan teliti. Pernyataan tersebut didukung oleh salah satu hasil wawancara dan hasil tes soal Himpunan yang telah dilakukan dengan subjek sebagai berikut:

$\mathrm{P} \quad$ : Apakah tidak ada rencana lain dalam menyelesaikannya?

S-3 : Gak ada Bu, saya pake rumus yang ada aja.

\section{Melihat Kembali}

Pada tahap ini dapat diketahui dari hasil wawancara dengan subjek. Pada soal pertama hingga soal ketiga subjek S-1 melakukan tahap melihat kembali, sedangkan subjek S-2 tidak melakukan tahapan melihat kembali. Tetapi untuk subjek S-3 ia melakukan pengecekan kembali pada soal pertama saja.

\section{Kesalahan Siswa Tipe Field Dependent dalam Menyelesaikan Soal Himpunan}

Subjek yang pilih sebagai siswa dengan tipe FD adalah Shali (S-4), Rio (S-5) Dan Danu (S-6). Dibawah ini peneliti mendeskripsikan hasil dari tes yang telah dilakukan. Berikut table deskripsi 
kesalahan siswa dalam menyelesaikan soal himpunan pada siswa tipe FD.

Tabel 2. Kesalahan Siswa FD dalam Menyelesaikan Soal Himpunan

\begin{tabular}{|c|c|c|c|c|c|c|c|c|c|c|}
\hline \multirow[b]{2}{*}{ Indiaktor } & & \multicolumn{3}{|c|}{ Subjek S-4 } & \multicolumn{3}{|c|}{ Subjek S-5 } & \multicolumn{3}{|c|}{ Subjek S-6 } \\
\hline & & $\begin{array}{c}\text { Soal } \\
1\end{array}$ & $\begin{array}{c}\text { Soal } \\
2\end{array}$ & $\begin{array}{c}\text { Soal } \\
3\end{array}$ & $\begin{array}{c}\text { Soal } \\
1\end{array}$ & $\begin{array}{c}\text { Soal } \\
2\end{array}$ & $\begin{array}{c}\text { Soal } \\
\mathbf{3}\end{array}$ & $\begin{array}{c}\text { Soal } \\
1\end{array}$ & $\begin{array}{c}\text { Soal } \\
2\end{array}$ & $\begin{array}{c}\text { Soal } \\
3\end{array}$ \\
\hline \multirow{2}{*}{$\begin{array}{l}\text { Memahami } \\
\text { masalah }\end{array}$} & + & $\sqrt{ }$ & & & & & & $\sqrt{ }$ & & \\
\hline & - & & $\sqrt{ }$ & $\sqrt{ }$ & $\sqrt{ }$ & $\sqrt{ }$ & $\sqrt{ }$ & & $\sqrt{ }$ & $\sqrt{ }$ \\
\hline \multirow{2}{*}{$\begin{array}{l}\text { Membuat } \\
\text { rencana }\end{array}$} & + & $\sqrt{ }$ & & & & & & & $\sqrt{ }$ & \\
\hline & - & & $\sqrt{ }$ & $\sqrt{ }$ & $\sqrt{ }$ & $\sqrt{ }$ & $\sqrt{ }$ & $\sqrt{ }$ & & $\sqrt{ }$ \\
\hline \multirow{2}{*}{$\begin{array}{c}\text { Melaksanakan } \\
\text { rencana }\end{array}$} & + & & & & & & & & & \\
\hline & - & $\sqrt{ }$ & $\sqrt{ }$ & $\sqrt{ }$ & $\sqrt{ }$ & $\sqrt{ }$ & $\sqrt{ }$ & $\sqrt{ }$ & $\sqrt{ }$ & $\sqrt{ }$ \\
\hline \multirow{2}{*}{$\begin{array}{l}\text { Melihat } \\
\text { Kembali }\end{array}$} & + & & & & & & & $\sqrt{ }$ & & \\
\hline & - & $\sqrt{ }$ & $\sqrt{ }$ & $\sqrt{ }$ & $\sqrt{ }$ & $\sqrt{ }$ & $\sqrt{ }$ & & $\sqrt{ }$ & $\sqrt{ }$ \\
\hline
\end{tabular}

Keterangan (+) Memenuhi Indikator

(-) Tidak Memenuhi Indikator

Berdasarkan indikator pada Tabel 2. Hasil analisis siswa dengan tipe Field Dependent adalah sebagai berikut.

\section{Memahami Masalah}

Berdasarkan hasil yang tes soal Himpunan dapat dilihat bahwa siswa dengan gaya kognitif FD tidak dapat menuliskan apa yang diketahui dan ditanyakan pada soal.

\section{Merencanakan Penyelesaian Masalah}

Pada tahap ini subjek S-4, S-5 dan S-6 belum memenuhi seluruh tahapan penyelesaian masalah. Terlihat pada soal nomor 3 semua siswa tidak ada jawaban yang tepat. Hal ini sesuai dengan penelitian yang dilakukan Widodo (2013) yang mengungkapkan bahwa kesalahan konsep terjadi karena siswa salah dalam memahami makna dari soal, salah dalam menggunakan rumus, teorema atau definisi tidak menyesuaikan dengan kindisi prasyarat.

\section{Melaksanakan Perencanaan}

Berdasarkan hasil tes soal Himpunan dapat dilihat bahwa semua subjek tidak memenuhi indicator yang ada. Hal tersebut sesuai dengan penelitian yang dilakukan oleh Mulyadi (2015) yang menyatakan bahwa kesalahan yang paling banyak dilakukan oleh siswa dalam menyelesikan soal cerita adalah kesalahan karena tidak mengetahui konsep atau terdapat miskonsepsi. Penyataan tersebut didukung dengan hasil wawancara dengan subjek S-6.

$\mathrm{P} \quad$ : Bagaimana langkah yang kamu lakukan untuk menyelesaikan soal?

S-6 : Gak ada bu, paling saya tulis yang saya tau aja. 


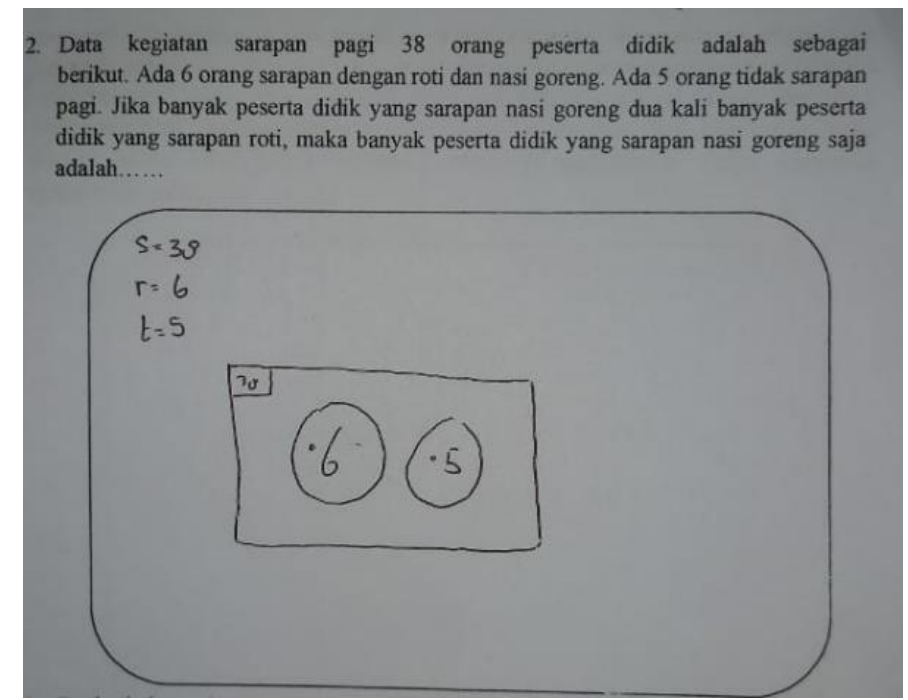

Gambar 3. hasil tes soal himpunan subjek S-6

\section{Melihat Kembali}

Tahap ini dapat diketahui dari hasil wawancara dengan subjek. Pada soal yang pertama hingga soal yang ke tiga subjek S-4 dan S-5 tidak melakukan tahap memeriksa kembali. Sedangkan subjek S-6 memeriksa kembali hanya pada soal pertama saja.

\section{KESIMPULAN}

Dari hasil penelitian dan pembahasan pada penelitian yang telah di lakukan oleh peneliti. Dapat disimpulkan bahwa siswa yang bergaya kognitif FI hampir keseluruhan dapat memahami masalah yang ada pada soal, dan membuat rencana penyelesaian masalah. Untuk tahap melaksanakan rencana penyelesaian masalah dan melihat kembali hasil yang diperoleh masih terlalu sedikit yang melakukannya. Dan untuk siswa yang bergaya kognitif FD dilihat dari keseluruhan jawaban soal tes Himpunan maupun wawancara belum terlihat bahwa siswa dapat memahami soal. Ketika siswa tidak paham akan masalah pada soal maka untuk tahap selanutnya pun tidak akan berjalan dengan baik.

Siswa dengan tipe FI sudah memahami permasalahan dan membuat rencana dengan baik. Hanya saja tidak melakukan tahap melaksanakan rencana dengan baik, maka dari itu siswa dengan tipe tersebut harus diberikan soal yang lebih menantang. Agar kemampuan nya dapat terasah lagi. Untuk siswa tipe FD dapat diberikan soal secara kontinu serta diberi bantuan secukupnya, karena siswa tipe ini sulit untuk memahami masalah pada soal.

\section{UCAPAN TERIMA KASIH}

Terimaksih kepada sumber yang terlibat dalam penelitian dan hasil penelitian ini. Termasuk informasi tentang sumber dukungan finansial yang diterima untuk diterbitkan. Tempatkan Ucapan Terimakasih, termasuk informasi tentang sumber dukungan finansial yang diterima untuk diterbitkan. 


\section{REFERENSI}

Barlian, Eri. 2016. Metode Penelitian Kualitatif dan Kuantitatif. Padang: Sukabima Press.

Cahyani, C. A., \& Sutriyono, S. (2018). Analisis Kesalahan Siswa Dalam Menyelesaikan Soal Pada Materi Operasi Penjumlahan dan Pengurangan Bentuk Aljabar Bagi Siswa Kelas VII SMP Kristen 2 Salatiga. JTAM (Jurnal Teori dan Aplikasi Matematika), 2(1), 26-30.

Khairunnisa, R., \& Setyaningsih, N. (2017). Analisis Metakognisi Siswa Dalam Pemecahan Masalah Aritmatika Sosial Ditinjau Dari Perbedaan Gender (Pada Kelas Vii SMP Muhammadiyah 5 Surakarta Tahun Ajaran 2016/2017) (Doctoral dissertation, Universitas Muhammadiyah Surakarta).

Kristofora, M., \& Sujadi, A. A. (2017). Analisis Kesalahan dalam menyelesaikan masalah matematika dengan menggunakan langkah Polya siswa kelas vii SMP. PRISMA, 6(1), 9-16.

Malau, L. 1996. Analisis Kesalahan Jawaban Siswa Kelas I Smu Kampus Nommense Pematang Siantar Dalam Menyelesaikan Soal-Soal Terapan Siswa Persamaan Linier 2 Variabel. Tesis tidak Diterbitkan. Malang: IKIP Malang.

Mulyadi, Riyadi dan Sri Subanti. 2015. “Analisis Kesalahan Dalam Menyelesaikan Soal Cerita Pada Materi Luas Permukaan Bangun Ruang Berdasarkan Newman's Error Analysis (Nea) Ditinjau Dari Kemampuan Spasial. "Jurnal Elektronik Pembelajaran Matematika. (www.jurnal.fkip.uns.ac.id/index.php/s2math/article/view/6180/4276).

Polya, G. (2004). How to solve it: A new aspect of mathematical method (Vol. 85). Princeton university press.

Sugiyono. (2010). Metode Penelitian Pendidikan. Bandung: CV Alfabeta

Wahyuni, S., Tandiayuk, M. B., \& Hamid, A. (2016). Penerapan Langkah- Langkah Polya Untuk Meningkatkan Hasil Belajar Siswa Dikelas Vii SMP Negeri 2 Sigi dalam Menyelesaikan Soal Cerita Persegi Panjang. Aksioma, 5(3).

Widodo, S. A. (2013). Analisis kesalahan dalam pemecahan masalah divergensi tipe membuktikan pada mahasiswa matematika. Jurnal pendidikan dan pengajaran, 46(2 Juli).

Wijaya, Yeni Kurnia dan Setyaningsih, Nining. (2018). Kesalahan Siswa dalam Menyelesaikan Soal Sistem Persamaan Linier Dua Variabel (SPLDV) Berdasarkan Newman's Error Analysis (NEA) Ditinjau dari Gaya Kognitif. Skripsi. Surakarta: UMS. 